\title{
Negotiations of Gender in Early Childhood Settings
}

\author{
Anette Hellman • Mia Heikkilä
}

(C) Springer Science+Business Media Dordrecht 2014

\section{Guest Editors: Anette Hellman and Mia Heikkilä}

Gender research has long focused on arguments that gender is constructed through discursive and overlapping social processes. However, there is still a minimal body of research concerned with how young children learn gender through social interaction in educational settings. This point has been made by a number of authors (Ärlemalm-Hagsér and Pramling Samuelsson 2009; Davies 2003; Martin 2011; Paecher 2007; Thorne 1993). Taking this as the starting point for this issue, we present new research and analyses that investigate negotiations in which young children from different parts of the world 'engage' with different aspects of gender. All papers focus on early childhood settings where children themselves in different ways negotiate and react to gender. Questions raised include: How can negotiations of gender be described and analyzed within early childhood education? When, where and by whom are gender relations produced?

Influential global discourses about children in research and policy documents discuss concepts such as competent children, children's rights, and children's influence. Dahlberg, Moss, and Pence (2007) noted that ideas about children and childhood are often constructed and negotiated through conflicting discourses. Children can be categorized as 'competent' while in another global discourse children are seen as 'not yets' and viewed, in the early childhood years, as only

\footnotetext{
A. Hellman $(\bowtie)$

Department of Education, Communication and Learning, University of Gothenburg, PO Box 300, 40530 Göteborg, Sweden e-mail: anette.hellman@ped.gu.se

M. Heikkilä

School of Education, Culture and Communication, Mälardalen University, PO Box 883, 72123 Västerås, Sweden e-mail: mia.heikkila@mdh.se
} 
gradually gaining the knowledge required to prepare them for school when they reach a specific age. These are not necessarily opposing positions although frictions can emerge between the different discourses. The discourse about children's competences and needs is particularly interesting in terms of issues of gender and education.

As discussed in the papers in this issue, children's competences and needs are often represented in ways that position girls and boys as having 'different' competences and needs. Gender, children, and childhood can be understood as situated global discourses, negotiated, and challenged both in relation to hegemonic global understandings as well as in relation to local conceptions and norms. Contributions made by the papers in this special issue focus on how representations of gender are performed/constructed in different national contexts and in different early childhood settings. This issue of IJEC includes papers on negotiations of gender from Sweden, Australia, Japan, and Estonia. One paper in this issue considers the issue of generating gender knowledges that are more inclusive to other-than-Western concepts and contexts. The research reported in this issue not only points at differences in gender negotiations across global contexts but also indicates similarities across contexts.

The first article, Interfering with gendered development: A timely intervention, authored by Mindy Blaise, discusses interpretations of gender concepts in relation to context. Instead of relying on colonial and Western developmental logic to understand and research gender, Blaise proposes interfering as a strategy toward generating gender knowledges that are more inclusive to other-than-Western concepts and contexts. The author shows how post developmental perspectives interfere with psychological and biological scientific logics that feed into common sense explanations of gender. Interference is discussed as one of a number of post developmental practices that can illuminate the social construction of gendered childhoods and the position of the child as agentic. The article ends by highlighting other-than-Western gender research that draws from post-Confucianism to interfere with the universal gendered girl and boy child. It is a move toward gathering and generating new gender knowledges.

Davies's (2003) research has shown how children, in order to be accepted as members of society, have to learn how to think by using language. Norms seen as 'natural' are intertwined with language and therefore in children's ways of thinking. Children learn how to act 'in the right way' by relating to others in the way that discursive practices have taught them. To understand how young girls and boys interact and negotiate local representations of gender is a starting point for several contributions in this issue. Another is intersectionality. Research has stressed the importance of analyzing gender in relation to other societal power structures including age, class, religion, ethnicity, and sexuality (Crenshaw 1995).

Anette Hellman, Mia Heikkilä, and Jeanette Sundhall present in their article, 'Don't be such a baby!' Competence and age as intersectional co-markers on children's gender, an analysis of how gender and age intersect in early childhood practice. This article picks up a discussion from the first article about interpretation of concepts, by showing how gender is created through intersection with other situated hegemonic norms and concepts. The paper uses data from a two-year 
ethnographic study in a Swedish preschool (Hellman 2010). Findings presented show how norms about age intersect with gender and create social positions that reflect notions of incompetent and competent children. Age and gender norms reinforce each other. The notion of 'being a baby' constitutes a powerful way to police the border between those who are and those who are not yet gendered subjects.

In the third article, Gender, order and discipline in early childhood education, authored by Ylva Odenbring, the starting point is in hegemonic discoursers of gender. Drawing on ethnographic fieldwork from a Swedish preschool class, her paper explores how the task of being a teacher's assistant can be critically understood in terms of how gender, discipline, and order are expressed in different duties in the daily practice of preschool. The results show that both boys and girls conform in taking the role as a teacher's assistant and the associated duties. However, one way of establishing order and discipline in the preschool classroom is to place girls next to noisy boys. This duty is proposed in this paper as serving as a 'damper' and is reserved only for the girls, in contrast to other teacher assistant roles.

Andra Siibak and Kristi Vinter analyze data in the fourth article, "No silly girls' films!" Analysis of Estonian pre-school children's gender specific tastes in media favorites and their possible implications for preschool learning practices from 25 focus group interviews with children aged 5-7 years, recruited from three geographically different preschools in Estonia. Their research investigates what kind of media content Estonian preschool children prefer and their favorite media characters who they considered as their role-models. While boys preferred actionadventure and scary movies and namely superheroes or characters with superpowers as their favorites, girls enjoyed family shows, films and comedies and liked fairies, angels, princesses, and other similar non-life-like fictional characters as their favorites. The findings indicated that preschool children were not only active and enthusiastic media watchers but they could also eagerly take the roles of coperformers of media in the focus group interviews by acting out scenes from programs and mimicking the activities of their favorite characters.

Also using media as a platform for discussing the negotiation of gender among young children, Mikako Hata in the fifth article Preschool girls and the media: how magazines describe and depict gender norms, illustrates gender processes from a Japanese perspective. Thirteen Japanese magazines published in 2013 were examined of which seven magazines catered for girls, three magazines catered to both genders, and three magazines catered to boys. Her results showed that girls' magazines included more information and illustrations about food, clothes, and hairstyles, and media celebrities such as popular musicians or fashion models. The article also revealed that the gendered patterns of interests and behaviors that the magazines conveyed to girls were not always aligned with the interests of the girls from analyses of the contributions to readers' pages. Mikako shows from her data that children are reactive and not just a passive audience on the content that the magazines conveyed.

Finally, in the article, "I Mean, the Queen's Fierce and the King's not": Gendered Embodiment in Children's Drawings", Susan Wright points out some 
methodological questions about the role of the researcher in working with young children, in order to understand how children create meaning about gender. Gender differences in children's artwork have been the subject of study for over 100 years but using another methodology this article speaks back and questions these stereotypes. Using social-constructivism as a theoretical framework, the methodology involved interlocutor-child dialogic improvisations, on a one-to-one basis, as each child engaged in graphic and body-based action while talking about aspects of the artwork and the processes of its creation through a free-form type of narrative. Semiotics is used as an analytical framework to describe three girls' drawings (aged 5-8 years) who were selectively sampled from a larger study that involved over 100 children in drawing 'what the future might be like.' These girls' graphic-narrativeembodied artifacts are discussed in relation to three key themes: spatial relations and meaning; allegory and fantasy; and metaphor, abstract reasoning, and connotation. The findings are discussed in relation social-cultural factors that might influences boys' and girls' gendered identities and, in turn, the content, form, and processes of their artistic creations.

\section{References}

Ärlemalm-Hagsér, E., \& Pramling Samuelsson, I. (2009). Många olika genusmönster existerar samtidigt i förskolan [Multiple and complex gender patterns in preschool]. Pedagogisk forskning $i$ Sverige, 14(2), 89-110.

Crenshaw, K. W. (1995). Mapping the margins: Intersectionality, identity politics and violence against women of colour. In K. Crenshaw (Ed.), Critical race theory: The key writings that formed the movement. New York: The New Press.

Dahlberg, G., Moss, P., \& Pence, A. (2007). Beyond quality in early childhood education and care: Languages of evaluation. New York: Routhledge.

Davies, B. (2003). Frogs and snails and feminist tales: Preschool children and gender. Cresskill, NJ: Hampton press.

Hellman, A. (2010). Kan Batman vara rosa? Förhandlingar om pojkighet och normalitet på en förskola. Gothenburg Studies in educational sciences 299. Akademisk avhandling. Göteborg: Acta Universitatis Gothoburgensis.

Martin, B. (2011). Children at play_Learning gender in the early years. Stoke on Trent, UK: Trentham. Paechter, C. (2007). Being boys, being girls_Learning masculinities and femininities. Maidenhead, UK: Open University Press.

Thorne, B. (1993). Gender play: Girls and boys in school. Maidenhead, UK: Open University Press. 